\title{
FORMATION OF THE INNOVATIVE PROJECT FINANCING MODEL IN MODERN CONDITIONS
}

\author{
Viktoriia Kachuriner ${ }^{1}$, Malvina Hrushko²
}

\begin{abstract}
The state of development of the leading countries of the world proves that its main factors are innovative high technologies, new equipment, a new organization of labour and production, a new motivation for entrepreneurship. They ensure the economic stability of micro and macro systems, their competitiveness both in the domestic and foreign markets. Given the limited nature of state financial resources, the problem of finding additional sources of financing for the purpose of activating the development of innovation activity in Ukraine is becoming increasingly urgent. Today, many countries are actively implementing modern models of financing of innovative projects. In many countries, hybrid financial instruments are transformed in the modern environment into hybrid investment models such as crowdfunding and crowdinvesting. Research of existing models of innovative economic development is always relevant, development tendencies are constantly changing under the influence of global conditions. In Ukraine, it is possible to predict the development of such innovative models as: a resource model without high-tech production (natural resources - production - money); innovative model (transformation of money for research into knowledge - transformation of knowledge into skills of workers and innovations transformation of innovations into goods - money); intellectual-donor model. An analysis of the world experience of using such forms of activation of innovation activity in the USA, Japan, Western Europe, the CIS, and other countries proves their relevance and prospects for Ukraine. At the same time, the efficiency of the functioning of innovation centres is largely determined by the proper level of financing of their activities, especially at an early stage. The model "university - innovation centres" aims to overcome the gap between education and the implementation of the knowledge gained in creating innovation. Within the framework of this model, two blocks are key: a block of joint research centres "university - industry" and a block of the creation of innovation centres and startup. The advantages of such a mechanism are: firstly, for business - direct state support for innovations, the possibility of investing under the state guarantees; and secondly, for the state - reduction of budgetary expenditures at the expense of funds attracted in the sphere of innovation activity, increase of innovation activity of priority sectors of the economy, distribution of innovative risks. The model of joint research centres "university - business structure" provides two variants of financing of such centres. The first option is based on the formation of a research centre in the form of corporation, which may include universities, private investors, local authorities, other sponsors and stakeholders. Traditionally, Ukraine has significant potential in some important fields of science, such as medicine, physics, astronomy, biology, chemistry, materials science, space science, and Earth science. Participation in Horizon 2020 allows creating additional opportunities for the successful development of these branches of science.
\end{abstract}

Key words: innovative model, innovation centre, innovative project, financing mechanism, Horizon 2020.

JEL Classification: O16, O38, H50, P42

\section{Introduction}

The state of development of the leading countries of the world proves that its main factors are innovative high technologies, new equipment, a new organization of labour and production, a new motivation for entrepreneurship. They ensure the economic stability of micro and macro systems, their competitiveness

Corresponding author:

${ }^{1}$ International Humanitarian University, Ukraine.

E-mail: kachuriner22@ukr.net

ORCID: https://orcid.org/0000-0003-2553-5071

${ }^{2}$ National University "Odessa Law Academy", Ukraine.

E-mail: malvina.grushko@gmail.com both in the domestic and foreign markets. Within the framework of integration processes for our country, there was a necessity to form own model of innovative development of the domestic economy. In these conditions, positive and effective transformations of Ukrainian society are possible only on the basis of the comprehensive use of all fundamental factors of social 
progress, the key importance of belongs to the science, the latest knowledge and technologies in the practical activities of all business entities.

Given the limited nature of state financial resources, the problem of finding additional sources of financing for the purpose of activating the development of innovation activity in Ukraine is becoming increasingly urgent. The mechanism of turnaround financing and related services can be: loan, credit, leasing, joint activity, financial investment. State financial institutions, which ensure the implementation of the state policy of supporting innovation activities in the priority directions of scientific and technological development, finance innovative projects under preferential terms of returning the provided financing.

Today, many countries are actively implementing modern models of financing of innovative projects. As a rule, such projects are of an investment or innovative nature but they are not always closely related to the main activities of the enterprise. However, for some types of businesses, the funding system for individual projects may become the main source of implementation. Project financing becomes one of the active forms of operational finance management. This is the ability to convert money into the final result - the project implementation, is important for the enterprise since it serves as an active tool for operational investment.

In many countries, hybrid financial instruments are transformed in the modern environment into hybrid investment models such as crowdfunding and crowdinvesting. Nevertheless, the application of even the most progressive models does not provide the maximum performance of the organization, if these models do not have an interconnected mechanism. In the context of building such a mechanism, the question arises about the establishment of effective systems for project management of an enterprise or entrepreneur. Today, a unique universal solution that simultaneously includes all effective tools of multiproject management does not exist.

In our opinion, there are still outstanding issues regarding the creation of a specific mechanism for financing the activity of local innovation projects. The methods and tools for such financing, as well as the mechanisms for investing and financing projects, their advantages for each business entity, need to be specified.

Research of existing models of innovative economic development is always relevant, development tendencies are constantly changing under the influence of global conditions. New countries-leaders emerge, which modernize their experience of financing innovative development, ineffective or fired forms of interaction disappear. Such a process is fleeting and changing.

The main purpose of the paper is to generalize foreign experience in the formation of models of innovative development of the economy and to define the main criteria for the identification of alternative ways on activating new mechanisms of financing innovative projects in Ukraine and identifying prospects for further cooperation of innovation centres and other economic entities.

\section{The methodology of research}

The theoretical foundations of innovative development and the issue of management of innovation processes are highlighted in the works of many well-known scientists, for example, in studies by Galchinsky A., Heiets V., Kinakh A., Seminozhenko V. (2002), Heiets V. (2003), Melnychenko O. (2012), Hamann M. (2004) and others, there are considered general theoretical issues of innovation management at macro and micro levels, the influence of the innovative component on the development of an enterprise or a country, and determined the importance of the introduction and development of various forms of innovation activity in modern development conditions.

The connection of innovations and the potential of a country or region are researched in scientific works by Onyshko S. (2004), Lugovy V., Gusev V., Knyazev V. (2002), Bubenko P., Semynozhenko V., Amosha O., Moiseyev G. (2006), and others. In addition, it should be noted that the conceptual framework for the adaptation of world innovation models of economic development has not yet been formed. Taking this into account, there is a need to generalize the world experience in relation to the model of innovation development, which is the purpose of this work.

Problems of financing innovation and increasing its activity during the last decade are widely investigated by modern scholars: Denisyuk V. (2010), Fedulova L., Volosyuk M. (2011), Martunyuk O. (2017), Nikolayenko Yu., Sakun O. (2015), Shostak L. (2010), Kim K., Hann I. H. (2014), Hervé F. et al. (2016), Baskerville R. F., Cordery C. J. (2014), and others. The main aspect of these studies is the state of innovation activity, sources and ways of its financing under the current conditions of integration of Ukraine's economy into the world economy. In spite of the current developments of scholars in the field of the theory and practice of financing innovation, the problem of finding alternative mechanisms of financing for innovation centres in Ukraine remains insufficiently revealed.

According to international financial organizations' data published in the specialized publications, Ukraine belongs to countries with a very low level of high-tech products in exports $(5 \%)$, while on average this figure in the world reaches $21 \%$ (Philippines $65 \%$, the USA $32 \%$, Ireland 41\%, the Netherlands 63\%) (Hamann, 2004).

Having analysed the state policy of developed countries in the field of innovative development by the degree of state regulation, two models of regulation of development of the country's innovative potential can be distinguished. 
The Anglo-American model of innovative development is characterized by complete autonomy and independence of entrepreneurship in innovation. Under such a model, market mechanisms themselves contribute to accelerating the innovation process, therefore, the state focuses its efforts on supporting the development of a market environment.

The second model of innovation policy is the French-Japanese model of innovative development, characterized by a significant influence of the state on the development of the innovation process, in particular, by non-market methods - through direct grants and subsidies to enterprises and organizations that carry out innovation activities. However, none of these models in pure form is used by any country (Shostak, 2010).

The world experience of becoming a modern technology market in the USA, Japan, Sweden, and other countries shows that the main element of the state policy in the developed countries are the programs of creation of technoecopolises and technopark structures as innovative centres, which developments provide the latest technologies to various fields of industrial and agricultural production, transport and communication, etc.

A striking example is Finland, in which the so-called "scientific-industrial incubators" or "business incubators" operate. In such incubators, future commercially attractive inventions go from idea to manufacturing of competitive products, which are of high demand in the global market for goods and services. These incubators combine universities, research and production centres, lawyers and managers, venture companies into one single link. By the way, the main form of providing budget funds is to provide free subsidies, grants for research projects on a competitive basis. It is noteworthy that in Finland, as in most developed countries, there are no preferences for those who create and implement innovative developments. From successful projects, the state receives a significant replenishment of the budget in the form of taxes.

Silicon Valley (California, USA) is the largest investment centre, in which highly qualified personnel are concentrated: scientists, engineers, designers, programmers, lawyers, managers, venture entrepreneurs.

In Europe, joint government decisions of the EU member states have formed a number of institutions that provide direct support to the innovation process: the European Investment Bank, the European Investment Fund, the Initial Capital and Eurotech Capital projects, as well as a special small business support program (Hamann, 2004).

The main investment institute in Europe is the European Investment Bank (European Bank - EIB). Almost half of its industrial-oriented loans are intended for small enterprises, with the priority given to providing venture capital to small companies working in the field of new technologies.

In Ukraine, one can predict the development of such innovative models:
1) resource model without high-tech production (natural resources - production - money);

2) innovative model (transformation of money for research into knowledge - transformation of knowledge into skills of workers and innovations - transformation of innovations into goods - money);

3 ) intellectual-donor model (an abbreviated version of the model (II), from which the stage of production is withdrawn).

As the practical experience of world countries with different levels and efficiency of economic development shows, the second model of economic reproduction is the most effective. However, in Ukraine today, the first and third models dominate: resource without hightech production (I) and intellectual-donor (III). The mentioned models in the strategic perspective have a relatively low level of efficiency, as they lead to the depletion of the country's resources, the leak of factors of production of the national economy abroad, and make it impossible to ensure high indicators of the welfare of the population (Onyshko, 2004; Shostak, 2010).

An innovative type of economic development is increasingly becoming the foundation that determines the economic strength of the country and its prospects in the world market. The main feature of the contemporary expansion of forces in the world is a significant gap between the leading countries that create the "innovative enclave" in the world from the less powerful countries, which are forced to fully depend on the position of "active players." In countries belonging to innovation leaders, there is a high concentration of the most profitable types of business (with the highest content of added value in the price of the product), mainly a high-tech structure of national production, the transfer of industrial-technological cycle of productions that are environmentally-friendly, resource-intensive, etc. abroad, concentration of the largest financial flows (Shostak, 2010).

An important point is the fact that the developed countries have started innovative development for quite a long time. The USA and Japan are the economic superpowers that produce almost $40 \%$ of the world's GNP. In the second half of the 1980s, Japanese exports to the USA reached tremendous proportions for the latter, which was one of the main causes of the escalation of the Japanese-American controversy. The USA remains the largest exporter and importer in the world. For example, the share of the US aerospace industry in world exports is 44 times higher than Japan, while in the world exports, Japanese cars are twice as large as American ones. Japanese cars accounted for about $70 \%$ of the US car market in the 1990s, which made an attempt in 1995 to set a $100 \%$ tariff for Japanese luxury cars. Japan filed a complaint to the World Trade Organization and won the case (Shostak, 2010). Besides motor industry, the most competitive industries in the Japanese industry include electronics and semiconductors, computers, 
office equipment, telecommunication equipment, home audio and video equipment, motorcycles, photographic equipment, machine-tool construction, shipbuilding, where Japanese companies have big advantages.

Taking into account the analysis of the innovative development of the abovementioned developed countries, it should be noted that the first-priority task of forming an innovative development model in Ukraine should be to overcome the false idea of the possibility of doing this by means of mechanical restoration of the necessary levels of state financing of the scientific and technical sphere. In this case, it is not only about the practical impossibility of accumulation of the necessary amount of funds in terms of the current state of public finances. Most importantly, it is the lack of prospects of investing in the restoration of the scientific sphere without the emergence of adaptive to modern economy chains of the relationship between science, technology, and production.

In Ukraine, innovation has not yet become a proper means of improving competitiveness. The need for a transition to an innovative model of development remains relevant and is substantially enhanced in modern external and internal circumstances.

It is worth noting that the model of the creation of innovation centres (in the form of technoparks, technopolises, business incubators etc., and the promotion of exclusively "high-performance" industries and productions) in Ukraine gives local effects but is not very effective over the low susceptibility of the economy to innovations (Fedulova, Volosyuk, 2011). Attempts to implement sectoral "technological leaps" in the conditions of maintaining the general unfavourable business and investment climate in the country, excessive fiscal pressure, the ineffectiveness of the institutional structure of the economy turn into losses in other sectors of the economy. Production of high-tech industries does not find sales in other industries due to the high technological gap and the lack of motivation for use, which significantly reduces the synergistic effect of innovation, so the effectiveness of such "growth points" levels out on a public scale. Therefore, the main task of innovative development policy is to ensure a balanced interaction of scientific, technical, and production potential, to develop and implement a mechanism for activating the innovation activity of business entities, and to disseminate innovations in all spheres of the national economy.

\section{Results and discussion}

An analysis of the world experience of using such forms of activation of innovation activity in the USA, Japan, Western Europe, the CIS, and other countries proves their relevance and prospects for Ukraine. At the same time, the efficiency of the functioning of innovation centres is largely determined by the proper level of financing of their activities, especially at an early stage. To work out alternative financing schemes for innovation centres, it is expedient to describe this mechanism by creating special state programs.

When creating such programs, it is advisable to take advantage of the US experience as one of the leading countries with an innovative type of the economy and the most effective mechanism for the formation of an innovation strategy. By adapting to the Ukrainian conditions of the development of innovation centres such American programs as Innovation Research Program, Technology Transfer Program, Small Business Technology Transfer Program, and Advanced Technology Program (Melnychenko, 2012), we propose to form a model "University - Innovation Centres Business".

The model of innovation project financing should be implemented at the following levels (Nikolayenko, Sakun, 2015):

- at the strategic level - Public-Private Partnership Agency, which should involve representatives of the public and private sectors. Powers of the Agency should include, first of all, the forecasting of the needs of the national economy, individual branches from the point of view of ensuring the technological advantages of their competitive development, competitive selection of innovative projects, creation or promotion of new and high-tech manufacturing, exhibition, information and marketing support of innovation activity;

- at the level of science-innovation centres (technoparks, industrial parks, science parks, innovation centres, research institutions, business incubators) that will assess the innovation capacity (market orientation) of research results, qualify innovation objects, provide accounting and tax assistance, patent protection, and registration of intellectual property rights to small innovative firms;

- at the level of implementation in production - commercial partnerships based on research institutions for the purpose of innovation activity, that is, commercialization of developments, which state scientific institutions will enter with intellectual property rights and private investors - with financial contributions;

- at the level of financing - Innovative Fund of joint public-private investment, which should be created in the form of a private joint stock company; formed in the form of a holding, $50 \%$ of the capital of which belongs to the state, and the rest - to private investors.

In order to form effective mechanisms of financial support for innovation activity, innovations in industry, and ensuring economic growth in Ukraine, it is expedient to introduce a separate structural element within the framework of the state financial system Innovation Bank. This would contribute to an increase in the total turnover of financing for innovation projects of centres. At the initial stage of activity, the state must 
hold majority shares in this bank. Other national cofounders of the bank will be large enterprises and any other interested solvent business entities, and subsequently, non-residents can be involved.

In order to protect against risk and guarantee the return of private capital to an investor in case of a risk event, it is expedient to authorize the insurance company for investment in innovation selected by the executive authorities. This company should work closely with all institutional structures, first of all, with the Innovation Bank and the Innovation Fund.

In order to ensure the co-financing of projects, it is necessary to form the following mechanism (Denisyuk, 2010):

- providing direct loans by the Innovative Bank for those projects that cannot use the usual channels of the attraction of credit resources. It will open additional sources of resources for technoparks and business incubators while ensuring the financial turnover and profitability of the bank;

- provision by the Innovation Fund of joint publicprivate investment for the implementation of projects selected by the Public-Private Partnership Agency. This mechanism provides for the development of strategically important developments and research areas for the country;

- financial support of residents of industrial parks investing in innovations: co-financing of salaries for personnel involved in research work (50\% is funded by the Innovation Fund);

- joint financing of projects, transfer to industrial parks of production with a greater value added (up to $40 \%$ is funded by the Innovation Fund). This would increase the attractiveness of the Ukrainian industrial parks, create a business case for private investment in park construction and registration of parks in the national register, and stimulate the transfer of more high-tech industries to the country;

- co-financing of projects selected on a competitive basis by the Public-Private Partnership Agency, initiators of the creation of innovation centres: budget financing $30 \%$ of the project cost, the rest - private companies or local self-government bodies;

- application of mechanisms of venture financing of risk innovative projects through the formation of joint venture capital funds at the regional level.

It is advisable to apply the experience of Israel and Great Britain. The share of specially created state investment funds in regional venture funds has become a catalyst for the development of venture capital investment and is still actively being implemented today. Both funds are created in the organizational-legal form of a limited partnership and operate under the guidance of private management companies (usually foreign ones). The funds of the state usually make no more than $50 \%$ of each regional fund and the rest should be attracted from private investors. Regarding the payment, there is the rule of the first victim in favour of the private investor (Denisyuk, 2010).

The advantages of such a mechanism are: firstly, for business - direct state support for innovations, the possibility of investing under the state guarantees; secondly, for the state - reduction of budgetary expenditures at the expense of funds attracted in the sphere of innovation activity, increase of innovation activity of priority sectors of the economy, distribution of innovative risks (Martunyuk, 2017).

The model "university - innovation centres" aims to overcome the gap between education and the implementation of the knowledge gained in creating innovation. Within the framework of this model, two blocks are key: a block of joint research centres "university - industry" and a block of the creation of innovation centres and startup. For the creation of the first block, it is advisable to take advantage of the US experience as a basis. Along with strategic business alliances over the past 30 years, the "university industry" partnerships have been actively developing in the USA. Financing in such cases is carried out on a contractual basis, and the owner of the research results is a financial company. The "university - industry" model has become so widespread that many institutions have created special centres (over 1000 throughout the USA) that serve such projects (Nikolayenko, Sakun, 2015). In our opinion, the stimulation of such cooperation contributes to accelerating the emergence of different types of innovation centres by combining the innovative potential of education and commercial progress, and the commercialization of innovations.

The model of joint research centres "university business structure" provides two variants of financing of such centres. The first option is based on the formation of a research centre in the form of corporation, which may include universities, private investors, local authorities, other sponsors, and stakeholders. Each corporate member of the Centre contributes to the joint fund an annual fixed membership fee, which is intended to fund fundamental research.

The next step is to introduce scientific research into production by creating a spin-off company. In case of its successful operation, the Centre's Fund should distribute the income received among the participants. Universities and institutions need to report on licensing, investments from foreign investors in research and development and spin-off companies, income from spin-off activities, the number of jobs created or developed social products in front of the Council of the Centre.

The second option involves participation in the financing of the innovative non-bank financial and credit institution "Small Innovative Business Support Fund", which was created in 2011 (Resolution of the Cabinet of Ministers of Ukraine (2011).

The Small Innovative Business Support Fund provides relatively small financial support to the 


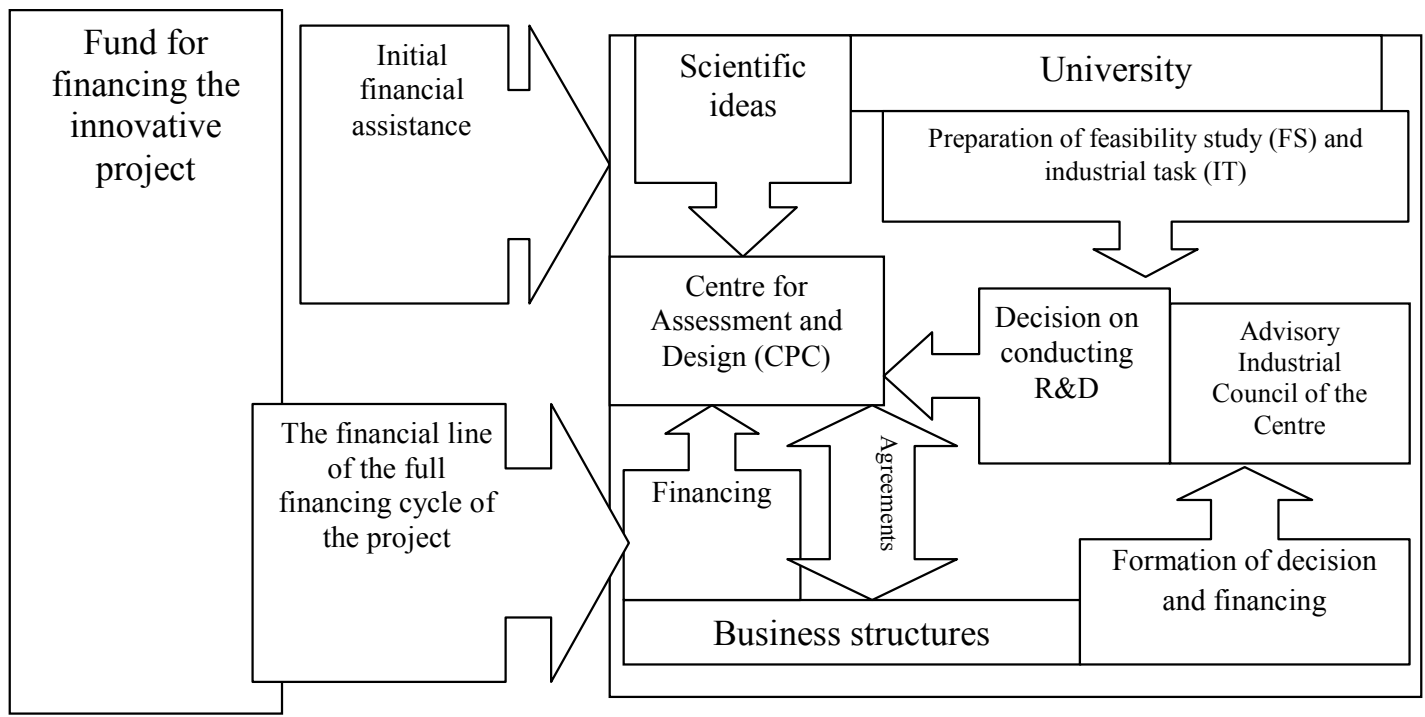

Figure 1. Formation of the Research Centre "University - Business Structures"

Source: improved by the authors on the basis of (Nikolayenko, Sakun, 2015)

centres $-20 \%$. At the same time, $80 \%$ comes from other sources - mainly from industrial companies. If the centre can prove its ability to carry out serious research, the Small Innovative Business Support Found provides a five-year grant that can be extended. The partnership of the parties in the centre is formalized through the adoption of joint decisions by the Advisory Industrial Council of the Centre, representatives of the university and business on conducting research works (the scheme is presented in Figure 1).

The indicator of success, according to the Fund's criterion, should be the amount of research carried out by the centre under contracts with industry. It is also determined that an important task for the state is to search for promising ideas at universities and research centres, to provide investment financing in the early stages of company development, to finance the development of business plans and research activities, and to expand the international cooperation of research organizations.

The following mechanisms can be applied to provide financing: project financing up to $30 \%$ through direct subsidies; allocation of grants to half of the cost for the company if it conducts research in cooperation with the university, and not only develops a new product; allocation for the company of risky loans to $60-70 \%$ of the cost of developing a new product or process.

The company is obliged to repay the loan if the development has been successfully introduced to the market; project financing up to two years, and in the case of favourable results of the development of a new product will continue for another 2-3 years in the form of a risky loan. Such measures may be entrusted to the Small Innovative Business Support Fund, as this does not contradict its statute and the purpose of creation.

The Horizon 2020 program is a key element of the EU's research and innovation, with significant resources allocated (80 billion euros) for 2014-2020. Research areas for project financing under the Horizon 2020 program cover both natural and social sciences by three main thematic components (see Table 1) (Seventh FP7, 2013).

Associate membership in Horizon 2020 allows Ukraine to participate in the Program under the conditions of a member state of the EU. In addition, this gives Ukrainian research groups the right to act as a leading partner within the consortium. Simultaneously with the acquisition of membership, an obligation to

Table 1

The main thematic priorities of the Horizon 2020

\begin{tabular}{|c|c|c|}
\hline Frontier science & Industrial leadership & Social challenges \\
\hline $\begin{array}{l}\text { European Research Council } \\
\text { Future and advanced technologies } \\
\text { The Marie Skłodowska-Curie actions for } \\
\text { skills, training and career development } \\
\text { Research infrastructures (including } \\
\text { electronic infrastructure) }\end{array}$ & $\begin{array}{l}\text { Leadership in Enabling and Industrial } \\
\text { Technologies (LEIT): nanotechnology, } \\
\text { advanced materials, biotechnology, advanced } \\
\text { industrial production, ICT, space } \\
\text { Access to risk financing } \\
\text { Innovations in small and medium enterprises }\end{array}$ & $\begin{array}{l}\text { Health, demographic changes } \\
\text { Food safety, sustainable agriculture, marine } \\
\text { research } \\
\text { Power engineering, transport, environmental } \\
\text { protection, climate } \\
\text { Europe in a changing world; protecting } \\
\text { freedom and security }\end{array}$ \\
\hline
\end{tabular}

Source: formed by the authors on the basis of Seventh FP7 (2013), Erasmus+ (2019) 
make financial contributions is established; however, half of such contributions may be covered at the expense of funds allocated to Ukraine within the framework of the European Neighbourhood Instrument.

In order to stimulate the cooperation of researchers from the countries of the Eastern Partnership and the EU member states and encouraging participation in Horizon 2020, the Commission has launched a project called "International Collaboration in Science, Technology and Innovation (STI) for the Eastern Partnership countries" (EaP PLUS) (Seventh FP7, 2013); Erasmus+, 2019).

The project consists of five events, including political dialogue and information campaigns:

1) Identification of strategic priorities by supporting political dialogue between the $\mathrm{EU}$ and the EaP participants and maximizing the association's impact on $\mathrm{H} 2020$;

2) Strengthening the interaction of researchers and deepening participation in the $\mathrm{H}$ 2020, that is, the organization of information days, cooperation with scientific diaspora and grants for networking;

3) Facilitating the implementation of a scientific and innovative interface that supports the community of best practices, i.e. analysis of joint patenting, clustering schemes, promotion of the concept of technology platforms to the Eastern Partnership countries;

4) Optimum framework conditions and strengthening policy and program coordination through conducting training seminars for policymakers in the sphere of scientific and technical innovation, strengthening coordination and interaction with EU member countries' policies and programs.

5) Communication and information campaigns, activities using innovative measures.

As of September 2017, Ukrainian research teams submitted 41190 applications to Horizons 2020, 117 of which were successful (9.8\%) and received funding in the amount of 17.23 million euros (Project ri-links2ua, 2017).

In order to facilitate the participation of Ukrainian scientists in Horizon 2020, a network of National Contact Points of Ukraine was established, which includes universities and institutes of the National Academy of Sciences of Ukraine. As of May 2018, there were 38 national contact points and 5 regional contact points (Erasmus+, 2019). Identify the key and largest projects that began to operate in Ukraine and for which it is possible to formulate and use the proposed model for financing innovative projects.

The ANIMA Project (Aviation Noise Impact Management through Novel Approaches) is aimed at developing a new methodology and tools for managing and reducing the impact of noise pollution on the environment. The project budget is 7.5 million euros for the period of 2015-2019 for a consortium of 22 partners from 11 countries. The Ukrainian partner is the National Aviation University (Aviation Noise Impact Management through Novel Approaches, 2018).
The ERA-PLANET project (European network for observing our changing planet) aims to strengthen Europe's leadership in the Global Earth Observing System of Systems (GEOSS). The ERA-PLANET project will provide advanced tools and technologies to support decision-making processes for better monitoring of the global environment in various fields of Earth observation. The project budget, implemented by a consortium of more than 40 institutions, is 11 million euros for the period from 2016 to 2020. Ukrainian partner: Space Research Institute under the National Academy of Sciences of Ukraine and State Space Agency of Ukraine (Explore P2Ps. Era-Learn, 2018).

The AMMODIT project (Approximation Methods for Molecular Modelling and Diagnosis Tools) focuses on the use of applied mathematics in medicine and life sciences. Budget: 823500 euros. Ukrainian partners: Institute of Mathematics of the NAS of Ukraine, Institute of Hydromechanics of the NAS of Ukraine, Taras Shevchenko National University of Kyiv, National Technical University of Ukraine "Igor Sikorsky Kyiv Polytechnic Institute” (Cordis, 2018).

The BLACK SEA HORIZON (BSH) project is directed to strengthen external relations of the EU with the targeted region by supporting biregional and regional political dialogue in science, technology, and innovation (STI). Budget: 1499503 euros. Ukrainian partner: Institute for Economics and Forecasting of the National Academy of Sciences of Ukraine (Ukraine Replication, Awareness and Innovation based on EGNSS, 2018).

\section{Conclusions}

Regardless of the mentality of the nation or the innovation market, the creation of an innovative development model is a prerequisite for the development of society; it is the key to its normal development. Of course, one can simply take over the foreign experience of innovative development of the economy, taking into account the specifics of the legislative framework and the state of the economy in general and effectively develop, however, if it were so easy, it would seem that all the countries of the world have long been on the path of effective innovative development. That is why we should not copy the achievements of our near and far neighbours but only learn from their mistakes.

Therefore, the proposed measures to improve the financial support of innovation centres are implemented through two state programs. These programs include the unification of innovative centres, financial institutions, industrial enterprises, higher education institutions, and private investors into a single system of interaction with the help of indirect instruments of state influence. The implementation of these programs will ensure the transition of production to a new innovative level, contribute to a positive shift in education, increase 
employment and, as a result, intensify the development of the national economy as a whole.

The signing with the EU of the Agreement on deepening relations and cooperation allowed Ukraine to participate in the organization of joint measures and events devoted to scientific and technical development. The association for the coordination of cooperation between Ukraine and the EU specifically emphasizes the need to promote the establishment of partnerships between the research sector and industry, as well as efforts to ensure the competitiveness of research results. According to the Association Agreement, in 2015, Ukraine became a full participant in the key EU program on research and innovation - Horizon 2020.

Traditionally, Ukraine has significant potential in some important fields of science, such as medicine, physics, astronomy, biology, chemistry, materials science, space science, and Earth science. Participation in Horizon 2020 allows creating additional opportunities for the successful development of these branches of science.

\section{References:}

Melnychenko, O. (2012). Innovative development of the national economy: challenges for the state, business and population. Public construction, no. 2.

Denisyuk, V. (2010). Commercialization of the results of scientific research: European experience and the state of Ukraine. Actual problems of scientific and technological and innovation policy in the context of the formation of a pan-European scientific space: experience and perspectives. Kyiv: Phoenix.

Resolution of the Cabinet of Ministers of Ukraine (2011). On the formation of the State Innovative Non-bank Finance and Credit Institution "Fund for Support of Small Innovative Business": dated 12.12.2011 No. 1396. Retrieved from: http://zakon2.rada.gov.ua/laws/show/1396-2011-\%D0\%BF

Bubenko, P., Semynozhenko, V., Amosha, O., Zemlyakin, A., Moiseyev, G. (2006). Perspectives of innovative development of regions. Kharkiv: "INZHEK" VD.

Galchinsky, A., Heiets, V., Kinakh, A., Seminozhenko, V. (2002). Innovative strategy of Ukrainian reforms. Kyiv: Knowledge of Ukraine.

Heiets, V. (2003). Innovative way of development is a modernization project of the Ukrainian economy and society at the beginning of the XXI century. Banking, no. 4.

Fedulova, L., Volosyuk, M. (2011). Trends in innovation and technological development of Ukrainian industry. Bulletin of the Khmelnytsky National University, vol. 3, no. 5.

Hamann, M. (2004). State Innovation Management: Ukraine and foreign experience. Kiev: Victoria.

Onyshko, S. (2004). Financial support of innovation development: monograph. Irpin: National Academy of Internal Affairs of Ukraine.

Lugovy, V., Gusev, V., Knyazev, V. (2002). System of priorities of the state innovation policy: Sb. sciences works of the Ukrainian Academy of Public Administration under the President of Ukraine. Kyiv: UADU. Issue 2.

Martunyuk, O. (2017). Methodology for diagnostics of the company management and technological maturity. International economics journal Montenegrin Journal of Economics, vol. 13, no 4.

Nikolayenko, Yu., Sakun, O. (2015). Proposals to improve the financing mechanism of local innovation centers in Ukraine. Scientific Herald of the International Humanitarian University. Series: Economics and Management, vol. 10. Retrieved from: http://nbuv.gov.ua/UJRN/Nvmgu_eim_2015_10_21

Shostak, L. (2010). Innovative Models of World Development. Lviv Polytechnic National University Institutional Repository. Retrieved from: http://ena.lp.edu.ua

Seventh FP7 Monitoring Report. Monitoring Report (2013). Retrieved from: https://ec.europa.eu/research/ evaluations/pdf/archive $/ \mathrm{fp} 7$ monitoring_reports/7th_fp7_monitoring_report.pdf\# view $=$ fit\&pagemode $=$ none Project ri-links2ua (2017). Retrieved from: https://ri-links2ua.eu/object/document/481

Erasmus+ (2019). Retrieved from: http://mon.gov.ua/activity/mizhnarodni-zvyazki/uchast-u-programax-eserazmus-ta-gorizont-2020/gorizont-2020.html

Aviation Noise Impact Management through Novel Approaches (2018). Retrieved from: https://cordis.europa.eu/ project/rcn/212369_en.html

Explore P2Ps. Era-Learn (2018). Retrieved from: http://www.era-learn.eu/network-information/networks/era-planet Cordis (2018). Retrieved from: http://cordis.europa.eu/project/rcn/194356_en.html

Ukraine Replication, Awareness and Innovation based on EGNSS (2018). Retrieved from: www.project-ukraine.eu/

Kim, K., Hann, I. H. (2014). Crowdfunding and the democratization of access to capital: a geographical analysis. Robert H. Smith School Research Paper. Retrieved from: http://ssrn.com/abstract

Hervé F. et al. (2016). Investor motivations in investment-based crowdfunding.

Baskerville, R. F., Cordery, C. J. (2014). Crowdfunding: a threat or opportunity for university research funding? 